

Digitized by the Internet Archive in 2011 with funding from University of Toronto 



CONTRIBUTIONS OF THE ROYAL ONTARIO MUSEUM OF ZOOLOGY

No. 30: EUROPEAN STUDIES OF THE POPULATIONS OF MARINE FISHES

\author{
By J. R. Dymond
}

Reprinted from Bulletin of the Bingham Oceanographic Collection, Vol. XI, Art. 4, May 1948. 



\title{
3. EUROPEAN STUDIES OF THE POPULATIONS OF MARINE FISHES
}

\author{
By John R. Dymond \\ Royal Ontario Museum of Zoology
}

\section{TABLE OF CONTENTS}

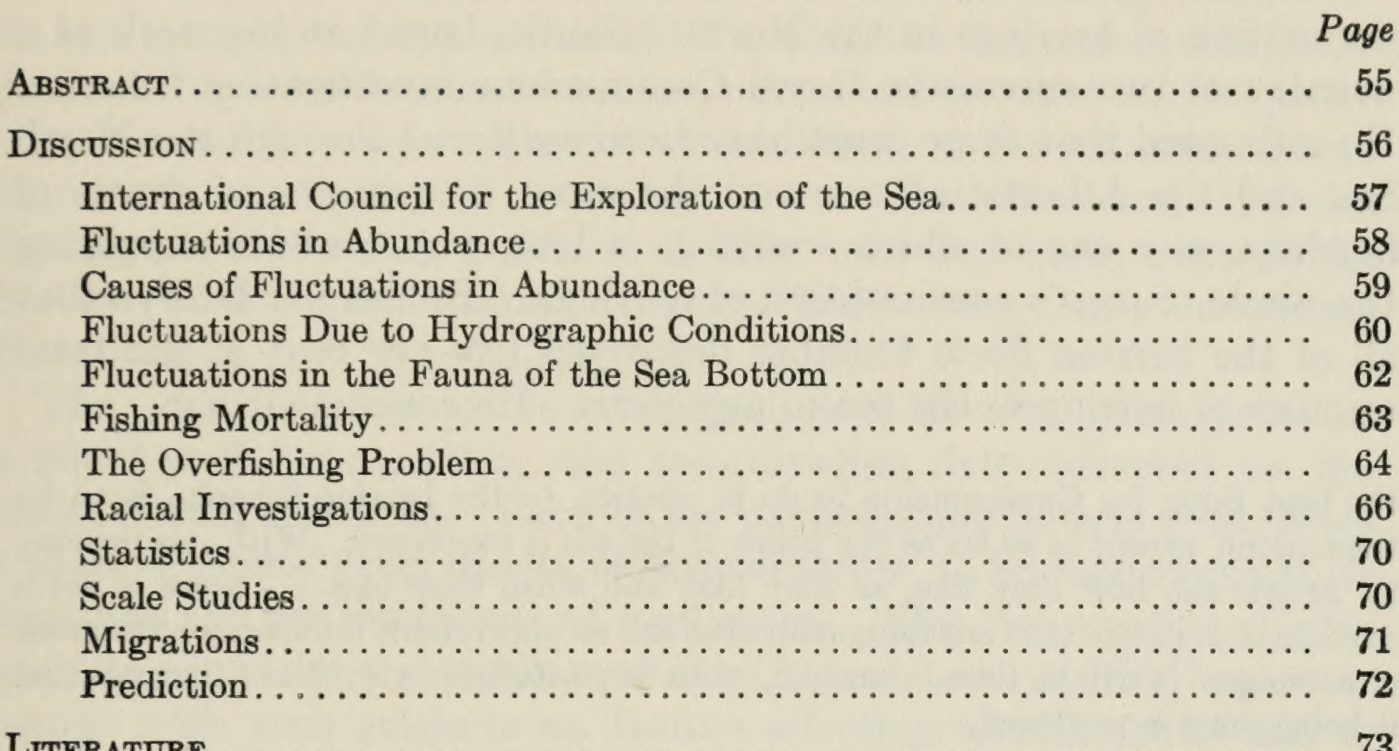

Literature. . . . . . . . . 73

\section{ABSTRACT}

The study of the fish populations of European waters developed chiefly in the Scandinavian countries and in Great Britain largely as a result of the economic importance of the fisheries to these countries.

Outstanding discoveries include the facts that some year-classes are fifty or sixty times as abundant as others, that such wide fluctuations characterize most of the important commercial species, that even when fish are abundant there are wide fluctuations in availability due to hydrographic conditions, and that great fluctuations in abundance also characterize the fauna of the sea bottom.

Demonstration of considerably increased mortality due to fishing has led to action designed to prevent overfishing. The International Council for the Exploration of the Sea has contributed materially towards the study of these problems and in initiating international action to meet situations uncovered.

An important feature of the study of populations has been the recognition and description of local races-more or less discrete populations having separate spawn- 
ing areas and characterized by average differences in certain morphological characters such as numbers of vertebrae, of scales and of fin-rays.

The discovery that the age of fish and certain characteristics of their life histories could be read from the scales has been basic to many phases of population work. The organization of statistics, especially those on an international scale, has also been an indispensable tool in population studies.

The understanding of populations and of the factors affecting them has reached the stage where in some species fishing probabilities have been attempted with considerable success.

\section{DISCUSSION}

Sixty-five years ago Huxley (1881) made some estimates of the population of herrings in the North Atlantic, based on his work as a member of two successive Royal Commissions investigating fisheries. He estimated that there must have been scattered through the North Sea and the Atlantic at one and the same time scores of shoals of herrings, any one of which would go a long way towards supplying the whole of man's consumption of herrings. He did not believe that all of the herring fleets together destroyed five per cent of the total number of herring in the sea in any year. He concluded that:

the best thing for Governments to do in relation to the herring fisheries, is to let them alone, except in so far as the police of the sea is concerned. With this proviso, let people fish how they like, as they like, and when they like. . . there is not a particle of evidence that anything man does has an appreciable influence on the stock of herrings. It will be time to meddle, when any satisfactory evidence that mischief is being done is produced.

It should be remembered in connection with this conclusion that it was reached in relation to the herring and at a time when trawling by steam-driven vessels had scarcely commenced.

The modern concern of European investigators, such as E. S. Russell (1942) and Graham (1943), with what they call the overfishing problem is chiefly about demersal species taken by trawling.

Fisheries research in Europe gradually developed during the last half of the nineteenth century, chiefly in the Scandinavian countries, in Great Britain and in Germany. The urge to study the fisheries arose largely from economic necessity. As E. S. Russell (1932) points out, in certain communities, notably in northern Norway where the population is mainly dependent upon fishing for a livelihood, the success or failure of the fishing is almost a matter of life or death. 
International Council for the Exploration of the Sea. The Council has played an important part in stimulating and co-ordinating research on population problems in European waters. It was formed in 1902 as a result of preliminary international conferences held in 1899 at Stockholm and in 1901 at Christiana.

The most pressing fishery problem at that time was the supposed depletion of the plaice in the North Sea through excessive fishing, and the chief work of the Council until the outbreak of the first great war was the investigation of the plaice fisheries. However, it had concerned itself also with herring, cod, mackerel, salmon and other food fishes as well as with hydrological and plankton investigations. At its last meeting before the war of 1914-1918 the Council decided on a program for extending its investigations to the North Atlantic generally, because it was recognized that conditions in the Atlantic had an important bearing upon conditions in the North Sea and that the development of steam power in fishing must inevitably extend the horizon of European fishing interests and consequently of fishing investigation.

The Council carries out no investigations of its own, although it has a small staff for recording and co-ordinating data collected by the participating countries. Each of the participating powers undertakes a share in agreed programmes of investigations, to be carried out at its own cost and by the means at its disposal. The co-operative studies undertaken under the auspices of the Council have usually been concerned with such subjects as, factors affecting abundance of fish in different areas, effect of destruction of undersized fish, effect of institution of size-limits of fish that are allowed to be landed, effect of installation of minimum mesh sizes of nets, closed seasons, nursery grounds, and whaling.

The countries supporting the work of the Council have varied from time to time. At present they include Great Britain, France, Spain, Belgium, Denmark, Eire, Holland, Iceland, Norway, Poland, Sweden and Finland.

The publications of the Council include:

Rapports et Procès-Verbaux, Publications de Circonstance, Journal du Conseil, Bulletin Statistique, Bulletin Hydrographique, Bulletin Planctonique, Bulletin Trimestriel, Faune Ichthyologique de l'Atlantique Nord, Annales Biologiques, Current Bibliography, and Special Publications. 
Fluctuations in Abundance. Wide fluctuations in abundance are a characteristic feature of animal life in the sea (Kemp, 1938). Because of the effect of such fluctuations on the economic life of Norway, a study of fluctuations was undertaken in that country in 1901 by Dr. Johan Hjort, then Director of Fisheries, aided by Einar Lea and Oscar Sund. A study of the age composition of the herring stocks of successive years soon led to the discovery that different year-classes varied markedly in their contributions to the stock of fish supporting the fishery (Hjort, 1914, 1926) and that wide differences in the success of various year-classes was one of the chief causes of fluctuations in the fishery. This principle was strikingly illustrated by the occurrence of the rich year-class of 1904, which dominated the Norwegian herring fishery for a long period of years. Other good year-classes were those of 1913 and 1918, while those of intervening years were poor.

In the case of the Norwegian cod, specially prolific brood-years were those of 1904 and 1912. Thompson's (1930) work on the haddock showed that in 1920, 1923, 1926 and 1928 the brood was much above the average, while in the intervening years the supply was moderate or poor. A specially good brood-year was found sometimes to contribute to the stock up to 25 times as many young haddock as a poor year. Other workers have found in the case of other species that it is not uncommon to find fish belonging to one year-class fifty or sixty times as numerous as those of another.

The fact that year-classes differ widely in their numerical strength has been demonstrated in the case of most of the important food fishes. This was emphasized in the reports of a meeting of the International Council for the Exploration of the Sea held in London in 1929, at which the problem of fluctuations was given special consideration (Rapp. Cons. Explor. Mer, 65, 68). Papers were given (1930) by Hjort, Sund, Thompson, Lea, Hodgson and others on fluctuations in cod, haddock, hake, plaice, herring, pilchard, sprat and lake herring.

The subject of fluctuations was also considered at a special biological meeting of the International Council held in 1936 (Comparative studies of the fluctuations in the stocks of fish in the seas of North and West Europe, Rapp. Cons. Explor. Mer, 101 [See, e. g., Sund, 1936]).

In commenting on the problem of fluctuations due to the success or failure of brood-years, Hjort (1930) stated that there was "no agreement between the various species of fish in this respect in the same year. Only in particular cases (herring in the coastal waters of Nor- 
way and the sea around Newfoundland, and cod in the coastal waters of Norway and Davis Strait) has it been observed that the same yearclasses were unusually abundant, on both occasions in waters situated widely apart."

Years when plentiful year-classes of cod were produced more or less over the whole range of the cod's distribution in the North Atlantic are given as 1924 and possibly 1912, 1917 and 1927. It is also believed that there are probably years of production of poor classes more or less general over wide areas. It is known for certain, however, that there are years in which good year-classes are produced in some regions and moderate or poor year-classes in others. It is assumed, therefore, that the causes of annual fluctuations are usually restricted both in space and time.

Causes of Fluctuations in Abundance. Search for an explanation of the causes of the wide differences in the size of different year-classes has brought out the fact that there is no necessary connection between the number of eggs produced in a particular spawning season and the number of fry which survive. Poor spawning years have often been good brood-years. It is usually assumed that the critical period of great mortality falls in the first few days or weeks after the eggs hatch. Factors suggested as influencing the hatching and survival of young include the following.

1. The origin of a rich year-class would require the contemporary hatching of the eggs and the development of the special sort of plants or nauplii which the newly hatched larva needed for its nourishment (Hjort, 1926).

2. The young larvae might be carried far away out over the great depths of the Norwegian Sea, where they would not be able to return and reach the bottom on the Continental shelf before the planktan in the waters died out during the autumn months of the first year of their life (Hjort, 1926).

Heavy gales may so disturb the sea bottom as to produce conditions unfavorable for the eggs or larvae.

Sund (1924) found a direct correlation between the rich year-classes of Norwegian cod and the years of smallest snowfall.

Long term studies such as those of F. S. Russell (1930-1940) are necessary for the elucidation of factors affecting the success of yearclasses. These studies at the Plymouth Station were aimed at determining the extent to which a planktonic population of young fishes, comprising some fifty or more species, ranges in its proportional com- 
position from year to year, and determining also whether or not a good or bad year for one species held good also for certain other species. It was hoped that, if a number of species were affected in the same way in one year, indications of some of the causes of such fluctuations might be obtained.

During the course of Russell's studies it was found that a serious decline in the numbers of young fish was correlated with a marked change in the amount of phosphate in the waters. Renewal of the phosphate in the channel appeared to be largely dependent on the inflow of mixed Atlantic water which is rich in phosphate because it contains water that has upwelled at the edge of the continental shelf. It seemed probable that the normal water movements off the mouth of the channel had undergone changes, and that these changes were indirectly responsible for the decline in the production of young fish. A by-product of the study was the discovery that certain planktonic animals are indicators of water-masses and are thus useful in tracing water movements.

The variation of such important constituents of sea waters as phosphate, silicate, nitrite and nitrate, seasonally and with depth, their replenishment and the part they play as factors of plant growth, have been studied by Atkins (1926) and Harvey (1928). Phosphate appears to be a limiting factor, at least at certain times.

The successful rearing of the fry of marine fish by Rollefsen (1939) is throwing light on the subject of the need of recently hatched fry on food of a certain size and kind. Plaice larvae have been successfully reared by feeding with nauplia of Artemia. Cod fry have also been fed on nauplia of Artemia, but success is not claimed in rearing this species.

Soleim (1942) has investigated the relation between high mortality of herring fry and poor plankton.

Fluctuations Due to Hydrographic Conditions. In contrast to the fluctuations in the fishery due to differences in the size of year-classes, which tend in most cases to be of short duration, there are fluctuations due to hydrographic conditions, which tend to be of long-term duration. Fluctuations due to differences in the success of brood-years are usually restricted to a certain species in a particular area, while fluctuations due to hydrographic conditions often extend over a period of years and involve much larger areas and large numbers of species. 
Fluctuations in migrations of herring to the coast do not necessarily reflect fluctuations in the stock; they produce changes in availability rather than changes in abundance. According to Runnstrøm (1937), in certain years Norwegian herring spawn mainly in deeper water and on more offshore grounds than in other years, and then the fishery bears on only a part of the spawning stock. The most extreme shifting of spawning places seaward seems to have taken place in the 'seventies of the last century when the spring-herring fishery on the southwest coast was a total failure for a series of years. Herring shoals were observed at sea, however, and herring roe was found in deep water. The abundance of herring fry in coastal waters indicated also that there had not been any considerable decrease in the spawning stock.

Through the use of the echo sounder the movements of spawning herring are now followed throughout the season. By this means it has been shown that the fishery has fallen mainly on shoals spawning close to the coast while great herring shoals have remained for weeks unexploited on more offshore grounds.

This type of fluctuation is also illustrated by the Bear Island cod fishery. In 1925, and for several years following, the Norwegians found great numbers of cod on the banks surrounding Bear Island. There had been a former occasion between 1874 and 1882 when cod were plentiful in this area. Between 1883 and 1925 the grounds were examined on a number of occasions but very few cod were found. Another instance is afforded by the cod fishery in West Greenland. At certain times large concentrations of cod appear on this coast and spread as far north as Disko Bay, but after a term of years their numbers suddenly decline and a protracted period of scarcity follows. Both these occurrences apparently were due to the fact that for a period of years in the 1930's the entire area from Greenland to Bear Island had become appreciably warmer. Increased sea temperatures probably of the order of $1.0^{\circ}$ to $2.0^{\circ} \mathrm{C}$. had allowed various species of fish to extend beyond the usual limits of their distribution. Hydrographic conditions in this case determined the size of that part of the stock that was at the disposal of the fishery in a certain area. The effect of hydrographic conditions may, therefore, mask the effects of fluctuations due to varying year-class sizes and may at times render fishery prediction unreliable.

The study of hydrography, and particularly of the currents, is 
fundamental for an understanding of the life and movements of the fish. The work of Graham (1924) and Graham and Carruthers (1925) on the relation of currents and other hydrological conditions to the life history and distribution of the cod afford examples of the correlation which can be established between hydrographical and biological conditions. In the study of such relationships the International Council plays a most important role in organizing systematic sampling through such agencies as steamships, lightships and research vessels. The tabulated results, mainly for temperature and salinity, are published annually in the Council's Bulletin Hydrographique.

Fluctuations in the Fauna of the Sea Bottom. Fluctuations also occur in the fauna of the sea bottom. Davis $(1923,1925)$, in the course of extended investigations on the Dogger Bank, found that certain small bivalves sometimes occurred over enormous areas, thus providing rich feeding for haddock and plaice. Some of these beds covered areas up to six or seven hundred square miles. One bed, whose population was estimated at 4,500,000,000,000 was composed largely of shellfish of a single year-group. These investigations which continued for several years showed that great changes took place from year to year in both extent and location of the beds.

Davis considered that the most probable cause of these fluctuations was changes in the course of the currents by which the larvae are passively transported. Species which are restricted to a particular type of bottom, if they do not happen to be deposited by the currents on suitable ground, produce scant crops. Subsequent investigations have shown that fluctuations in the fauna of the sea bottom, as in the case of the fishes, are the rule rather than the exception and that this holds good also in the littoral region.

Blegvad (1914) has investigated the food-chains of fish and fish larvae down to their ultimate elements.

Petersen and Boysen-Jensen (1911) and Petersen (1914, 1918, 1922, 1924) were the first to apply quantitative methods to the study of bottom fauna of the sea. For use in his studies, Petersen invented a bottom sampler, since known as the Petersen grab, by means of which he was able to bring up the soil and animals contained in it from a definite area of bottom. As a result of his studies of the fauna of sea bottom, Petersen developed the idea of communities, natural groups of species inhabiting more or less well defined areas which could be 
mapped. He recognized and mapped the location of eight types of communities in Danish waters. These were defined with reference to "characteristic species." One of his communities, for instance, he called the Macoma community from the prominence of the small bivalve Macoma baltica in it. Each community had fairly definite relations to depth of water, character of bottom, and probably also to such factors as temperature and salinity. Although Petersen recognized the importance of soil texture in determining the distribution and abundance of bottom organisms, this character has been still further emphasized by Davis (1925) who is inclined to substitute for the Petersen community the principle of soil associations.

Fishing Mortality. In regulating fishing in an effort to maintain the maximum continuous yield it is necessary to have information on rates of mortality due to fishing and to natural causes. Attempts to estimate reductions in populations arising from each of these causes have been based on the results of age analysis of fish stocks and of tagging experiments.

At a meeting of the International Council held in Berlin in 1939 the results of such studies were discussed by E. S. Russell, Graham, Thursby-Pelham, Raitt, Jensen and others (Rapp. Cons. Explor. Mer, 1939, 110). Since the results have also been summarized by E. S. Russell (1942) it is perhaps sufficient for the present purpose to quote one or two examples of the sort of results obtained.

For the haddock of the North Sea, Raitt (1939) concluded:

Of the second-year frequency of the brood of 1923 , for instance, $15 \%$ was removed in the third year, a further 50 in the fourth, and 20 in the fifth. Of the second-year frequency of the brood of $1933,65 \%$ was removed in the third, a further 25 in the fourth, and nine in the fifth, leaving only one per cent. as against 15 in the case of the brood of 1923. By the end of its third year the ranks of the 1933 brood were reduced by two-thirds of their second-year strength, which was as much as the 1923 brood suffered in its third and fourth years together. The average age to which the 1923 brood survived was four, and that of the 1933 brood less than three.

These results give a measure of the increase in the rate of mortality between 1923 and 1933.

In extensive plaice-tagging experiments carried out from 1929 to 1932 (Hickling, 1938) on the continental side of the southern North Sea, during which nearly 20,000 fish were marked, it was found that, excluding the smaller fish which are not returned in their true proportions, the percentage recaptured in the first year after tagging varied 
from 40 to 55 depending on locality. Judging from the numbers recaptured, it was concluded that there was a general rate of decrease in the stock of the order of 70 per cent per annum, a rate which would leave only two fish per thousand marked still surviving at the end of the fifth year of life.

The Overfishing Problem. A great deal of attention has been given in Europe to what is called the Overfishing Problem. Overfishing is defined as that condition in which the more you fish the less you catch. One statement of the situation is as follows:-If we start with an unfished or virgin stock and gradually increase the amount of fishing, we get for some time a continuously increasing yield accompanied shortly by a decreasing catch-per-unit-of-fishing-effort. But the yield does not go up in direct proportion to the amount of fishing; the ascending curve of yield begins to flatten out, and there comes a time when a maximum yield is obtained. Thereafter, if fishing is still further increased, the total yield falls off. That is what is meant by overfishing - the state in which the more you fish the less you catch.

If we wish to obtain the maximum steady yield from a stock, we must fish neither too much nor too little but at an intermediate rate, such that the number caught multiplied by their average weight is, and remains at, a maximum. If we fish too little, we do not catch a sufficient number to give the maximum steady yield in weight. If we fish too much, the average weight of the fish caught is too low to give the maximum yield. There must be, it has been concluded, for every stock of fish an optimum rate of fishing which will give the maximum steady yield (subject, of course, to variations due to natural fluctuations, which, however, cancel out over a period of years, and to variations in growth-rate).

A year-class of fish, after it has survived the heavy mortality incidental to its early life, will, if protected from fishing, increase in total weight for some years, the loss due to natural mortality being well over-compensated by the growth of the survivors. The only comparison I have been able to find between a virgin or unfished stock of fish is that quoted by E. S. Russell (1942). The population of plaice on newly discovered grounds in the Barents Sea was found by Atkinson (1908) to consist almost entirely of large fish, mostly over $40 \mathrm{~cm}$. and mostly mature. In contrast to this the population of plaice in the North Sea, which had been fished commercially, consisted of fish 
mostly under $40 \mathrm{~cm}$. in length, and the proportion of mature fish was much less than in the Barents Sea. The average size at first maturity is approximately the same in both areas, namely $39-40 \mathrm{~cm}$.

Ever since Petersen's (1894) work on plaice in Danish waters there has been general agreement that it must pay the industry to allow fish to grow to a medium size. $\mathrm{H}$; studies emphasized the fundamental importance of rate of growth a ad of food supply. The limited amount of food restricts the production of fish. "A stock of plaice with a low growth-rate will not yield the same annual production as a stock with rapid growth; a very dense, slowly growing stock will give but a very poor yield, as almost all the food will go simply to the maintenance of life and next to nothing can be used for growing purposes." Rapid production and early cropping were, in Petersen's view, the things to aim at in the regulation of fisheries.

E. S. Russell (1942) points out that in the early days of fishery science most workers thought that the main thing to aim at was to keep up the supply of mature fish so that an abundant supply of eggs and larvae and young fish might be assured. It was thought important, therefore, to prevent the capture or destruction of sexually immature fish, and very high size limits were advocated. Petersen pointed out that such measures might easily defeat their own ends if they resulted in producing overcrowded stocks of young fish, which grew slowly and consumed a great amount of food to little purpose. He advocated size limits of a moderate kind.

Some writers have exaggerated Petersen's view and oppose all measures for the protection of undersized fish. Up to a certain point fishing is good for a stock, since it clears out the accumulated stock of old slow-growing fish. It thus enables the remainder to grow more quickly and makes room for the oncoming brood. The thinning of younger fish should result in increased growth-rate and, therefore, of productiveness. Up to a point, yield can be increased by increasing fishing, but after this maximum is reached, increased fishing produces a less weight of fish (see also Graham, 1943).

There seems to be general agreement on the part of European fishery biologists that there is too much fishing for demersal fish and that the fish are being taken too young. Through the machinery provided by the International Convention on Mesh and Size Limits, undersized fish are protected from capture. 
Racial Investigations. One of the aspects of fish populations to which a great deal of research has been devoted in Europe is the existence of so-called local races. Within the total area of distribution of most of the species of fish that have been investigated, local populations have been found which can be distinguished by morphological and other characteristics. Thus the cod of the North Sea, of the Norwegian coast, and of Iceland, are separate stocks, each with its own spawning grounds and areas of distribution, and each distinguished from the others by the possession of morphological characteristics peculiar to it.

One of the first workers who made a careful study of the differences between local populations was Heincke. Matthews (1886), in an account of his studies on differences among Scottish herrings, refers to Heincke's "elaborate investigations into the varieties of the herring of the Baltic, including a few from the North Sea (Peterhead and Norway) and whose results appear in an excellent report published by the German Fishery Commission (Jahrsbericht der Comm. Z. Wissensch. Untersuch der deutschen Meer, 1878. 1882)." Natthews $(1886,1887)$ used 14 body proportions, as well as counts of fin-rays and keeled scales in his study of differences among the summer and winter herrings of the Scottish coasts. He emphasizes the necessity of examining large numbers of specimens, mentioning the "amount of almost 'drudgery' entailed in an investigation of this nature . . . In my own case, the mechanical work entailed amounted to the taking of about 16,000 measurements on the herrings, with over 20,000 subsequent calculations."

Heincke (1898), who is usually given credit for demonstrating the existence of "races" among herring, showed that fish from different areas have characteristics peculiar to themselves. Local populations, he believed, could be identified by their body proportions and by the number of certain structures. The body proportions he used included length of head and the distance from the head to other parts of the body. Other characters used included number of vertebrae, number of rays in certain fins and number of scales along the underside of the fish.

Williamson (1900) followed with work on the mackerel using 27 characters. Later workers have limited their observations to fewer characters such as vertebral and fin-ray counts, which has enabled them to make their studies on very much larger numbers of individuals. 
Thus in Schmidt's (1930) racial investigations on the cod, only two characters were always examined, namely the number of vertebrae and the number of rays in the second dorsal fin. Only occasionally were the number of pectoral and branchiostegal rays examined. His studies involved the examination of about 20,000 specimens from 114 stations distributed over the greater part of the range of the species in the Atlantic.

These investigations showed that the cod of the North Atlantic consist of a number of more or less distinct populations, differing from one another in a number of morphological characters. In vertebrae and fin-rays of the second dorsal it was found that the number increased from south to north in the open waters. Thus, in European waters the lowest values were found west of the British Isles and the highest in northern Norway. Similarly in American waters, the lowest were found off the coast of the United States and the highest off northern Newfoundland and Labrador. There was also a difference in the average values on the two sides of the Atlantic such that the number of vertebrae increased from east to west. From west of Scotland, where the lowest number of vertebrae (51.47) was found, the number progressively increased around the Faroes, Iceland, East Greenland and West Greenland to Labrador and northern Newfoundland, where the highest value (55.46) was found. Paralleling these differences in the number of vertebrae, the average values for the second dorsal fin showed an increase from south to north on both sides of the ocean and an increase from west of the British Isles over the Faroes, Iceland and Greenland to Newfoundland. In European waters, the number of second dorsal fin-rays practically never reached 20 , whereas average values above 20 were the rule in American waters.

Typical values were as follows:

Area

Nantucket shoals

St. John's, Newfoundland.

Belle Isle Strait

West Greenland

East Greenland

Iceland

Northern Norway

Southern Norway

English Channel

Rockall Bank, west of British Isles
Vertebrae

52.90

54.91

55.46

53.60

53.14

$52.29-53.26$

53.82

52.44

51.75

51.47
Second dorsal fin-rays

19.74

20.48

20.86

20.32

20.04

19.23-19.94

19.84

19.55

18.75

19.46 
Marked differences were found between vertebral numbers and number of rays in the second dorsal fin between inshore (or shallower) and offshore (or deeper) water, the former having the lower values. Examples were as follows:

Area

Innermost part of Trondhjem Fjord, Norway Outside the fjord

In Gulf of St. Lawrence

Outside the Gulf of St. Lawrence
Vertebrae

52.35

53.76

$53.58-53.86$

$54.16-54.29$
Second dorsal fin-rays

19.24

20.13

$19.96-19.71$

$20.00-19.87$

Schmidt (1917 to 1930; see also Smith, 1921, 1922), in addition to his racial studies of cod, made a series of very important contributions to the racial investigations of other species. One of the species on which much work was done was Zoarces viviparus. This viviparous fish, he pointed out, was exceptionally well suited for such studies. Thus one could compare mother and offspring in respect of a whole series of characters, which were already fully developed in the yet unborn progeny. Moreover, local populations of Zoarces differed unusually widely in a number of characters from those of neighbouring populations. Thus populations inside the Danish fjords sometimes had as many as nine fewer vertebrae on the average than those living outside. The middle parts of the fjords occupied an intermediate position in such respects. ". . . no closely investigated fish species," he said, "shows such great differences from population to population."

Analyses of ten successive year-classes from the same locality showed only very small variations, or less than one in the average number of vertebrae. Transplantation of samples of the same population to a new environment produced a significant change in the number of vertebrae, or more than one on the average. He also carried out experiments on hatching three different lots of trout (Salmo trutta) eggs from the same parent at different temperatures. A slight variation was observed in the number of vertebrae of fishes from the different lots.

Runnstrøm (1937), in his review of Norwegian herring investigations, points out that there exist different spawning communities in Norwegian waters which do not mix to any great degree. Some of these communities spawn on the coastal grounds while others spawn on more offshore grounds, visiting the coastal waters in the large herring stage only. 
The investigation of these localized breeding populations was facilitated by the fact that fish appear on somewhat small sharply defined banks and in shoals consisting only, or for practical purposes only, of one biological group of a species. Therefore, the investigation of local populations was much easier in such waters as those of Norway and Iceland and of the Faroes than in more extended waters like the North Sea where the topographical features of the depths of the bottom are not so distinctly marked.

As to the causes of the morphological differences which characterize races, Hjort (1930), referring to the proceedings of a special meeting of the International Council for the Exploration of the Sea held in 1928 (Rapp. Cons. Explor. Mer, 1929, 54) reported that there was then a "somewhat sharp division of opinion between those, who regard the formation of races as the result of fortuitous hereditary combinations of characteristics, and those who regard it as due to an interplay of the power of adaptation shown by the animals concerned and the physicochemical conditions predominating in particular areas of the sea."

One of the reasons for the belief that environmental conditions can and do alter the characters by which races are distinguished is that such characters are not fixed but may vary from year to year in the one localized population. On the basis of such evidence, Jensen (1939b) concluded that "as regards both plaice and the dab the number of anal fin rays seems to be positively correlated with the temperature of the water during the time at which the larvae are quite small. 1 degree C. corresponds to about 0.4 anal fin rays."

Schmidt (1930) gave it as his opinion that "Fishery biologists are evidently unanimous that external factors are capable of altering the average characters by which races in the fishes are determined. This has been proved directly by experiment in the common trout (Salmo trutta L.) and in the million fish (Lebistes reticulatus [Peters] Regan) by varying the temperature during which the development in the 'critical period' took, place . . .

"It would, however, be quite wrong to ignore the fact that the differences in the average characters by which the races are determined may also be of a hereditary, genotypical nature . . ."

At a meeting of herring experts, held under the auspices of the International Council at the Fisheries Laboratory, Lowestoft, England, in 1935, several papers dealing with the herring stocks of various areas were presented; some of these dealt with "races" in this species 
(see Andersson, Davis, LeGall, Hodgson, Poulsen, Runnstrøm, Schnakenbeck, Tåning and Wood, 1936).

Statistics. Since many phases of fishery research are based on fishery statistics, systems for the collection of these statistics have been organized in most European countries and the International Council early gave attention to the compiling of international statistics of catch. A summary of the statistics for northwestern Europe is published annually by the International Council as the "Bulletin Statistique."

In Great Britain fishing vessels provide information as to the quantities and kinds of fish landed, classified at least roughly as to size, where they were taken, what gear was used, the length of the voyage, and the number of hours actually spent in fishing. This information is collected daily at all the main fishing ports in Great Britain. An account of the methods used in collecting statistics is given by $\mathrm{E}$. S. Russell and Edser (1925) and Edser (1925).

Supplementing the general information obtained from the commercial statisties, more specialized data as to size-composition of the catches are collected by a special staff working partly on fishing vessels at sea and partly at coastal markets. In 1929, 914,000 fish were measured at sea and 69,500 in the markets. In addition the agecorapositiion of the stocks are determined especially for plaice, cod, herring and haddock. 20,000 plaice otoliths were examined by the English staffs in 1929.

Scale Studies. The development of techniques for determining the age and other facts of the life history of fishes from examination of their scales has contributed greatly to the study of fish populations.

Much of the early work on age determination and the correlation between the growth of the body and of the scales was carried out in connection with the Norwegian herring investigations by Dahl, Lea and others. They, of course, based their investigations on earlier work by such men as Hintze (1888) and Hoffbauer (1899), who had interpreted the rings on the scales of carp of known ages. The history of the advancements and refinements in scale-reading techniques have been traced by Lee (1920) and Graham (1929).

The study of scales has been found useful not only in determining the year-class to which fish belong but also in identifying fish of different types of life history. Local populations often differ in spawning 
times and rates of growth. For instance one type of Norwegian herring was found to have an abnormally small increment of growth in its third year. Such characters as this, which can be read from the scales, have been useful in recognizing populations and in studying the composition and recruitment of fish stocks.

Migrations. One of the first questions investigated under the auspices of the International Council was the extent to which fluctuations in the fisheries might be due to mass movements of fish coming onto grounds where they were taken by fishermen in some years and not in others. As already explained, it has been found that, while some fluctuations in the fishery are caused by variations in the movements of fish, there are enormous actual differences in abundance from time to time. The movements of fish have been traced in part by tagging and in part by the recognition of discrete populations through racial studies.

Several species of fish, including the cod and herring, have been shown during their life-time to carry out a migratory movement between a breeding place and a feeding place often separated by many hundreds of miles. For instance, one large cod population spawns about the latitude of the Lofoten Islands. From here the young are believed to be carried mainly north and east to the Barents Sea by the current which flows up the coast of Norway. On reaching maturity these fish are said to return to the spawning grounds off the west coast of Norway.

E. S. Russell (1932) says that in general "the life-history and migrations of a fish-group . . . take place within a closed circle; as a rule the fish move up-stream to spawn and their eggs and larvae are distributed downstream by the currents; spawning areas and feeding areas are often distinct and may be widely separated, and migrations are mainly for the two purposes of feeding and spawning." Reference in support of this statement is made to the papers of Damas (1909) and Schmidt (1909). Hjort's (1914) paper contains a chapter on the spawning and migrations of the cod.

Hodgson (1934) describes a similar movement for the herring.

. . we find the spawning migration is against the stream, or contra-natant as it has been called. Thus the herring, in common with many other fish, carries out the obvious movement in going up stream to spawn, so that under normal conditions its young will be brought back to the same area whence the parents came. 
Also, in the case of the plaice, Buchanan-Wollaston (1923-1926) found that the great majority of this species in the North Sea collect for spawning in a particular area off the estuary of the Thames in winter, where a tongue of warmish water extends up from the Channel and that their eggs and larvae are carried north and east by the prevailing current to the shallow continental flats, where they find suitable conditions for their further development.

Prediction. Knowledge of the populations of several species and of the factors affecting them has reached the stage where forecasts of probable abundance are possible. This is due in large part to the ability to recognize year-classes and to compare their relative abundance as they first enter the commercial fishery (Hodgson, 1932). Such forecasts have been issued for haddock, cod, herring and mackerel and in the main they have turned out to be remarkably accurate.

It must be remembered that estimates of the relative strength of year-classes based on observations of young fish as they enter the fishery are estimates of abundance and not necessarily of availability. Fish may actually be abundant and not available to the fishermen because they do not appear at times or at places where fisherman have been in the habit of finding them. Runnstrøm (1937), as already mentioned, points out that certain fluctuations in the spring herring fishery are due to variations in the migrations of the herring to the spawning grounds. In certain years the herring spawn mainly in deep water and on more offshore grounds than in other years, and then the fishery bears only on a part of the spawning stock. The use of the echo sounder in recent years has overcome variations to some extent in the fishery due to hydrographical conditions, although this is still one of the least understood factors responsible for fluctuations in the fisheries.

Jensen (1939a) discusses the role of hydrographical factors in determining the yield of mackerel in Danish waters. Their immigration from the North Sea seemed to be determined by the inflow of water. Pelagic fish, having no sense of the direction of water movement, follow the current passively. Predictions based on observations of water movements failed in three years and came true in eleven. 


\section{LITERATURE ${ }^{1}$}

Andersson, K. A.

1936. The herring groups in the Skagerak, the Kattegat and the Baltic. Rapp. Cons. Explor. Mer, 100 (2): 11.

AtKINs, W. R. G.

1926. A quantitative consideration of some factors concerned in plant growth in water. J. Cons. int. Explor. Mer, 1 (2): 99-126; 1 (3): 197-226.

Atkinson, G. T.

1908. Notes on a fishing voyage to the Barents Sea in August, 1907. J. Mar. biol. Ass. U. K., 8: 71-98.

\section{Blegvad, Harald}

1914. Unders $\phi$ gelser over naering og ernaeringsforhold hos havbundens invertebrate dyresamfund $\mathrm{i}$ danske farvande. (Food and conditions of nourishment among the communities of invertebrate animals found on or in the sea-bottom in Danish waters.) Rep. Danish biol. Sta., 22: 37-124; Supplement: $1-45$.

Buchanan-Wollaston, H. J.

1923. The spawning of plaice in the southern part of the North Sea in 1913-14. Fish. Invest., (2) 5 (2): 1-35.

1926. Plaice-egg production in 1920-21. Fish. Invest., (2) 9 (2): 1-36.

DAMAS, D.

1909. Contribution à la biologie des gadides. Rapp. Cons. Explor. Mer, 10 (B3): 1-277.

Davis, F. M.

1923. Quantitative studies on the fauna of the sea bottom. No. 1. Preliminary investigations of the Dogger Bank. Fish. Invest., (2) 6 (2): 3-54.

1925. No. 2 Results of the investigations in the southern North Sea. Fish. Invest., (2) 8 (4).

1936. A contribution to the "race question." Rapp. Cons. Explor. Mer, 100 (2): 12-13.

EDSER, T.

1925. A short account of the statistics of the sea fisheries of England and Wales. Rapp. Cons. Explor. Mer, 36: 3-27.

\section{Grafam, Michael}

1924. The annual cycle in the life of the mature cod in the North Sea. Fish. Invest., (2) 6 (6).

1929. Studies of age determination in fish. Part II. A survey of the literature. Fish. Invest., (2) 11 (3): 1-50.

1939. The sigmoid curve and the overfishing problem. Rapp. Cons. Explor. Mer, 110: 15-20.

1943. The fish gate. Faber and Faber, Ltd., London. 196 pp.

1 The following references are not intended to be by any means exhaustive. It is hoped, however, that they are adequate to lead the reader to the discovery of the more important contributions to the subject. 


\section{Graham, Michael and J. N. Carruthers}

1925. The distribution of the pelagic stages of the cod in the North Sea in 1924 in relation to the system of currents. Fish. Invest., (2) 8 (6): 2-31.

HaRver, H. W.

1928. Biological chemistry and physics of sea water. University Press,

HeINCKE, F. Cambridge. 194 pp.

1898. Naturgeschichte des Herings. I. Die Lokalformen und die Wanderungen des Heringes in den europäischen Meeren. Abh. Deutsch. Seefisherei Ver., 2 (1): CXXXVI, 128 pp.

HrCkLING, C. F.

1938. The plaice marking experiments 1929-1932. Fish. Invest., (2) 16 (1): $1-80$.

Hintze, G.

1888. Karpfensucht und Teichbau. Treba.

HJORT, JoHAN

1914. Fluctuations in the great fisheries of northern Europe. Rapp. Cons. Explor. Mer, 20: 1-228.

1926. Fluctuations in the year classes of important food fishes. J. Cons. int. Explor. Mer, 1 (1): 5-38.

1930. Fluctuations in the abundance of the various year-classes of food fishes. I. Introductory address. Rapp. Cons. Explor. Mer, 65: 5-9.

Hodgson, W. C.

1930. XV. Fluctuations in the herrings of the southern North Sea. Rapp. Cons. Explor. Mer, 65: 129-133.

1932. The forecasting of the East Anglian herring fishery. J. Anim. Ecol., 1: 108-118.

1934. The natural history of the herring of the southern North Sea. Ed. Arnold and Co., London. 120 pp.

1936. The present state of knowledge concerning the origin and distribution of herring populations in western European waters. The Southern Bight. Rapp. Cons. Explor. Mer, 100 (2): 19-20.

\section{HOFFBATER, C.}

1899. Die Alterbestimmung des Karpfen an seiner Schuppe. Allg. FischZtg., Jg. 23: 341-343.

HUXLEY, T. H.

1881. The herring. Nature, London, 28: 607-613.

JENSEN, A. J. C.

1939. On the laws of decrease in fish stocks. Rapp. Cons. Explor. Mer, 110: $85-96$.

1939a. The Danish forecasts of the yield of some fisheries. Rapp. Cons. Explor. Mer, 109 (3): 75-77.

1939b. Fluctuations in the racial characters of the plaice and the dab. J. Cons. int. Explor. Mer, 14 (3): 370-384.

Kemp, Stanley

1938. Oceanography and the fluctuations in the abundance of marine animals. Nature, London, 142: 777-779; 817-820. 
LEA, EINAR

1930. Fluctuations in the stock of fish. Herring. Rapp. Cons. Explor. Mer, 68: 85-93.

LEE, R. M.

1920. A review of the method of age and growth determination in fishes by means of scales. Fish. Invest., (2) 4 (2).

Le GaLl, Jean

1936. The present state of knowledge concerning the origin and distribution of herring populations in western European waters. Rapp. Cons. Explor. Mer, 100 (2): 15-18.

Matrhews, J. D.

1886. Report as to variety among the herrings of the Scottish Coasts. Pt. I. 4th Rep. Fish. Bd. Scot., App. F, No. 4: 61-98.

1887. Report as to variety among the herrings of the Scottish Coasts. Pt. II. 5th Rep. Fish. Bd. Scot., App. F, No. 8: 295-316.

Petersen, C. G. J.

1894. Om vore flynderfiskes biologi og om vore flynderfiskeries aftagen. (On the biology of the flatfishes and on the deerease of our flatfish fisheries.) Rep. Danish biol. Sta., 4: 1-147.

1914. Havets bonitering. II. Om havbundens dyresamfund og om disses betydning for den marine zoogeografi. (Valuation of the sea. II. The animal communities of the sea bottom and their importance for marine zoogeography.) Rep. Danish biol. Sta., 21: 42-68.

1918. Havbunden og fiskenes ernaering. En oversigt over Arbejderne vedrörende vore farvandes bonitering i 1883-1917. (The sea bottom and its production of fish food. A survey of the work done in connection with valuation of the Danish waters from 1883-1917.) Rep. Danish biol. Sta., 25: 1-58.

1922. On the stock of plaice and the plaice fisheries in different waters: a survey. Rep. Danish biol. Sta., 29: 43 pp.

1924. A brief survey of the animal communities in Danish waters based upon quantitative samples taken with the bottom sampler. Amer. J. Sci, (5) $7: 343-354$.

Petergen, C. G. J. and P. Boysen Jensen

1911. Havets bonitering. I. Havbundens dyreliv, dets næring og mængde. (Valuation of the sea. I. Animal life of the sea bottom, its food and quantity.) Rep. Danish. biol. Sta., 20: 3-73.

Poulsen, E. M.

1936. The herring stocks of the transition area. Rapp. Cons. Explor. Mer, $100(2): 20-22$.

RAITT, D. S.

1939. The rate of mortality of the haddock of the North Sea stock 1919-1938.

Rapp. Cons. Explor. Mer, 110: 65-79.

Rollefsen, Gunnar

1939. Artificial rearing of fry of sea water fish. Rapp. Cons. Explor. Mer, 109 (3): 133. 


\section{RUNNBTR $\varnothing$ M, SvEN}

1936. The distribution of the Atlanto-Scandian spring herring. Rapp. Cons. Explor. Mer, 100 (2): 24-28.

1937. A review of the Norwegian herring investigations in recent years. J. Cons. int. Explor. Mer, 12 (2): 123-143.

\section{Russeut, E. S.}

1932. Fishery research: its contribution to ecology. J. Ecol., 20: 128-151.

1939. An elementary treatment of the overfishing problem. Rapp. Cons. Explor. Mer, 110: 5-14.

1942. The overfishing problem. University Press, Cambridge. $130 \mathrm{pp}$.

Russell, E. S. AND T. EDSER

1925. The fishery statistics of England and Wales. J. roy. statist. Soc., 88: 221-250.

RUssell, F.S.

1930. The seasonal abundance and distribution of the pelagic young of teleostean fishes caught in the ring-trawl in offshore waters in the Plymouth area. J. Mar. biol. Ass. U. K., N. S. 16: 707-722.

1935. The seasonal abundance and distribution of the pelagic young of teleostean fishes caught in the ring-trawl in offshore waters in the Plymouth area. Pt. II. J. Mar. biol. Ass. U. K., 20: 147-179.

1936a. The seasonal abundance of the pelagic young of teleostean fishes in the Plymouth area. Pt. III. The year 1935, with a note on the conditions as shown by the occurrence of plankton indicators. J. Mar. biol. Ass. U. K., 20: 595-604.

1936b. The importance of certain plankton animals as indicators of water movements in the western end of the English Channel. Rapp. Cons. Explor. Mer, 100 (3): 7-10.

1937. The seasonal abundance of the pelagic young of teleostean fishes in the Plymouth area. Pt. IV. The year 1936, with notes on the conditions as shown by the occurrence of plankton indicators. J. Mar. biol. Ass. U. K., 21: $679-686$.

1938. On the seasonal abundance of young fish. V. The year 1937. J. Mar. biol. Ass. U. K., 22: 493-500.

1939. On the seasonal abundance of young fish. VI. The year 1938. J. Mar biol. Ass. U. K., 23: 381-386.

1940. On the seasonal abundance of young fish. VII. The year 1939, January to August. J. Mar. biol. Ass. U. K., 24: 265-270.

\section{SCHNAKENBECK, W.}

1936. The present state of knowledge concerning the origin and distribution of herring populations in western European waters. Rapp. Cons. Explor. Mer, 100 (2): 28-31.

Sснмірт, ЈонS.

1909. The distribution of the pelagic fry and the spawning regions of the gadoids in the North Atlantic from Iceland to Spain. Rapp. Cons. Explor. Mer, 10 (B4): 1-229. 
1917a. Racial investigations. I. Zoarces viviparus $\mathrm{L}$. and local races of the same. C. R. Lab. Carlsberg, 15 (3): 279-396.

1917b. Racial investigations. Il. Constancy invegtigations continued. C. R. Lab. Carlsberg, 14 (1): 1-18.

1918. Racial studies in fishes. I. Statistical investigation with Zoarces viviparus L. J. Genet., $\gamma:$ 105-118.

1919a. Racial studies in fishes. II. Experimental investigations with Lebistes reticulatus (Peters) Regan. J. Genet., 8: 147-153.

1919b. Racial investigations. III. Experiments with Lebistes reticulatus (Peters) Regan. C. R. Lab. Carlsberg, 14 (5): 1-8.

1919c. Racial studies in fishes. III. Diallel crossings with trout (Salmo trutta L.). J. Genet., 9: 61-67.

1920. Racial investigations. V. Experimental investigations with Zoorces viviparus L. C. R. Lab. Carlsberg, 14 (9): 1-14.

1921a. Racial investigations. VII. Annual fluctuations of racial characters in Zoarces viviparus L. C. R. Lab. Carlsberg, 14 (15): 1-24.

1921b. Racial investigations. VIII. The numerical significance of fused vertebrae. C. R. Lab. Carlsberg, 14 (16): 1-5.

1930. Racial investigations. X. The Atlantic cod (Gadus callarias L.) and SMith, KiRstine some local races of the same. C. R. Lab. Carlsberg, 18 (6): 1-72.

1921. Racial investigations. VI. Statistical investigations on inheritance in Zoarces viviparus L. C. R. Lab. Carlsberg, 14 (11): 1-60.

1922. Racial investigations. IX. Continued statistical investigations with Soleim, P. A. Zoarces viviparus L. C. R. Lab. Carlsberg, 14 (19): 1-42.

1942. Årsaker til rike og fattige årganger av sild. Rep. Norweg. Fish. Invest., 7: 1-39.

Sund, Oscar

1924. Snow and the survival of cod fry. Nature, London, 118: 163-164.

1930. II. The renewal of a fish population studied by means of measurement of commercial catches. Example: The Arcto Norwegian cod stock. Rapp. Cons. Explor. Mer, 65: 10-17.

1936. The fluctuations in the European stocks of cod. Rapp. Cons. Explor. Mer, 101 (3): 1-18.

Tining, A, V.

1936a. The herring stocks of the Faroes, Iceland and Greenland. Rapp. Cons. Explor. Mer, 100 (2): 32-33.

1936b. Review of fluctuations in the stock of cod at Greenland, Iceland, the Faroes and in Danish waters. Rapp. Cons. Explor. Mer, 101 (3): 19-21.

ThOMPSON, HAROLD

1930. VI. Fluctuations in the North Sea haddock stock. Rapp. Cons. Explor. Mer, 65: 35-44.

Thursby-Pelham, D. E.

1939. The effect of fishing on the stock of plaice in the North Sea. Rapp. Cons.

Explor. Mer, 110: 39-63. 
WrLLAMson, C. H.

1900. On the mackerel of the east and west coasts of Scotland. 18th Rep. Fish. Bd. Scot.: 294-329.

WOOD, HENRY

1936. Scottish herring race investigations. Rapp. Cons. Explor. Mer, 100 (2): 34-35.

\section{DISCUSSION}

Van Oosten: This paper is now open for discussion.

Huntsman: You apparently consider, Professor Dymond, that the theory of overfishing is based on the conclusion that it pays to let the fish get bigger. Do you think that European investigators have excluded the fishing up of the accumulated stock as well as the purely economic factor to which you have referred, and that they have really shown that it does pay to let these particular fish get bigger?

Dymond: I don't think I can answer the question. The term "overfishing" means exactly what they say: The more you fish the less you catch. That is apparently a fact there.

Burkenroad: The North Sea is supposed to have tremendously more fishing than any of our North American waters. Therefore, we shouldn't necessarily think it is essential to follow European conclusions on this side of the Atlantic. We haven't the same intensity of fishing here.

Herrington: Georges Bank produces much more for its area than the North Sea. The Bank is just a small fraction of the size of the North Sea.

Burkenroad: Is that so? Of all species or just a few?

Herrington: All species.

Needler: I don't think there is much doubt of the greater fishing intensity in the North Sea. The North Sea fishery has succeeded in reducing the size of the commercial species much more than in any of our areas in the west.

Kolbe: Isn't the size of the carnivorous fish important? I like to maintain that the larger a carnivorous fish is, feeding largely on other fish, the less fish flesh it gives rise to in terms of the potentialities of the basic plankton; this is because it is eating a lot of fish that have taken years to grow. Therefore, if your fish become smaller due to fishing in the North Sea, you can maintain a bigger population than you could on your Georges Bank.

Herrington: On Georges Bank the haddock, which is a bottom feeder, doesn't feed on other fishes.

Burkenroad: The productivity relationships are terribly complicated. You have a dynamic situation, not static. When a fish eats food it releases nutrients. A fisherman is interested in standing crops; that is, he cannot fish at a level of population that will not permit him to draw his net through the water and bring in a quantity of material greater than a certain minimum. But you can have a large production of fish with a small standing crop, at a high rate of turnover. 
Herrington: Mr. Kolbe, I think your statement is still correct, that the higher you go in the feeding cycle the smaller will be the population. The corn-hog ratio and the corn-beef ratio are examples of that. It takes so many pounds of feed to produce one pound of meat.

Burkenroad: Dr. Taylor has calculated the ratio between phosphate and nitrate in what we take out of the sea in our annual catch in the United States and the amount in the area of the fishery. The fraction we take out is insignificant.

Needler: The overfishing conception in the North Sea is not based on the total production at all. Specific reference is made to certain species of fish. One cannot criticize the conception on the basis of the total productivity and plankton produ ${ }^{2}$ tivity and so on. They still say that, in spite of certain species being overfished, the total production is not yet overfished. There are still very large quantities of herring and other species which are not overfished. Overfishing to the stage that Prof. Dymond says, where the more you fish the less you get, is limited to certain species on certain grounds and not to the entire productivity of any area or to any one species over the entire area. So that it boils down to what I think Mr. Herrington said earlier, that they are concerned not with reducing the total production but with maintaining the proportion of that production which lies in certain species. If certain species are more desirable than others, as they evidently are, it may be an undesirable thing to reduce these species as far as the others. That, I think, is the claim for overfishing.

Huntsman: The herring constitute the great bulk of the catch of the North Sea

Needler: So that the total take has not been affected-not to the extent of fishing. more and getting less. In fact, already, right now with food scarce, the English are using the machinery only to about 50 per cent because they can't get rid of the catch.

Huntsman: The rule that the more you fish the less you catch may be true for the haddock and halibut. However, it isn't a general rule for the bottom fishes.

Dymond: The trouble there is that when you haul your net over a certain bank you get everything there. It is a matter of compromise.

Huntsman: The best case for study seems to be the halibut in the North Sea. I would like to see the results critically studied. I would like to see whether it pays to let them get bigger.

Dymond: The halibut is one of the fish on which they are trying to make a quantitative study. It is a much more difficult situation than off the west coast where there are only two countries to deal with. In the North Sea they have half a dozen countries, and it is very difficult to get them to agree on even a method of research.

Herrington: Why don't we adopt a halibut program on the Atlantic as well as the Pacific? Are we willing to trade 10 for one-that is, 10 pounds of cod or other species for one pound of halibut?

Needler: I think it goes even further than that. You can't build up the production of halibut-at least you can't reduce the catch of small halibut and let them grow bigger-without reducing the catch of other fish that have several times the value. 
Burkenroad: I think the point about desirability is a fundamental one. How is one fish determined by long-term policy-makers to be more desirable than another? A fish that is more in demand one year may lose its lead in value the next year because consumers' tastes change. There are no satisfactory studies defining the extent to which the availability of the fish affects the demand for it. Desirability is neither constant nor objectively determinable, and I doubt that we can safely limit our science to attempts to prevent one equally nutritious and harvestable fish from replacing another. Local and temporary changes are important, but they ought not to obscure our thinking about basic principles.

Herrington: Professor Dymond mentioned the belief in a critical point in the survival of the young, which might be one or two days in the early stages of development. With poor conditions during that critical period you'd have a poor year-class. A short time ago Sette published a paper on mackerel which I think for the first time provided some information on the mortality rate of the young from the egg stage to the time they reach several inches. It was based upon a repeated series of hauls taken over the nursery grounds for mackerel, using plankton nets with current meters to measure the volume of water strengths. In that way it was possible to reduce the catch to terms per cubic meter or some such constant. The whole area was covered. As I recall, it was found that there was a relatively constant mortality rate through the egg and larval period with no exceptionally critical point. If you increased the over-all rate only slightly over the entire period of time, that slight increase would cause a big decrease in the number of survivals. The mortality rate over the whole period of the larval life appeared to be the determining factor rather than extremely high mortality at a particular stage.

Dymond: This theory of the Europeans, and your statement about the mackerel, seem to assume that the critical factor is not whether the fish hatch but whether they survive after they are hatched. Do we all assume, and if we do are we correct in assuming it, that the conditions for hatching are not so critical as the conditions for survival after hatching?

Needler: I think there is some evidence that survival is usually more important than the variation in number of eggs and that hatching is less important. It is the conditions in the first year of life or the first few months-not a particular day or week - which, of course, are basic in predictions.

Van Oosten: If there is no further discussion we shall now call for the next paper. 







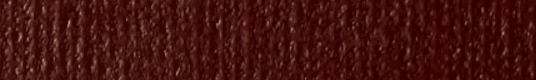

6.

6.1

(5)

1.12)

3.73)

W

(1)

(1)

17.

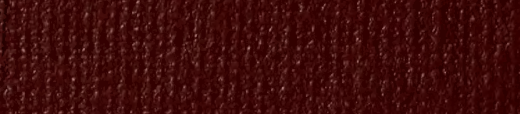

Whon 